\title{
ASTHENOPIA: DIAGNOSIS, TATALAKSANA, TERAPI
}

\author{
Pande Putu Arista Indra Pratama ${ }^{1}$, Komang Hendra Setiawan², Ketut Indra Purnomo ${ }^{3}$ \\ ${ }^{1}$ Prodi Kedokteran, Universitas Pendidikan Ganesha \\ ${ }^{2}$ Prodi Kedokteran, Universitas Pendidikan Ganesha \\ ${ }^{3}$ Prodi Kedokteran, Universitas Pendidikan Ganesha
}

e-mail: pande.arista@undiksha.ac.id,komanghendras@gmail.com, lodresss@gmail.com

\begin{abstract}
Abstrak
Asthenopia (kelelahan mata) merupakan sekumpulan gejala berupa permasalahan pada penglihatan (visual), mata (okular), dan muskuloskeletal yang umumnya terjadi hilang timbul. Keluhan ini sering muncul akibat pengaruh penggunaan perangkat digital dalam waktu yang lama terutama lebih dari 6 jam perhari. Penderita asthenopia secara global mencapai 60 juta orang yang didominasi usia muda. Gejala asthenopia yang paling sering dirasakan adalah keluhan mata kering, kesulitan dalam memfokuskan objek, mata tegang, mata lelah, dan sakit kepala. Diagnosis asthenopia dapat dilakukan secara subjektif dengan menggunakan kuesioner standar ataupun secara objektif dengan pemeriksaan lanjutan. Pemeriksaan yang dapat dilakukan berupa pengukuran Critical Flicker-fusion Frequency (CFF), pengukuran frekuensi berkedip, kemampuan akomodasi, serta refleks cahaya dan ukuran pupil yang dapat memberikan gambaran lebih jelas ke arah asthenopia. Tatalaksana dan terapi pada asthenopia diberikan untuk meredakan gejala dan mengatasi penyebabnya seperti terapi untuk mengatasi mata kering, koreksi gangguan refraksi, terapi gangguan akomodasi dan vergensi, dan penggunaan kacamata filter cahaya biru. Walaupun asthenopia terjadi secara hilang timbul, penyakit ini dapat menjadi menetap dan berkembang menimbulkan keluhan permanen. Artikel ini ditulis berdasarkan hasil literature review dari publikasi hasil penelitian terkait diagnosis, tatalaksana, dan terapi asthenopia yang sudah dipublikasi. Penulisan artikel ini diharapkan dapat dijadikan acuan dalam menindaklanjuti kasus asthenopia sehingga prevalensi dan insidensinya dapat ditekan.
\end{abstract}

Kata Kunci: asthenopia, diagnosis, tatalaksana, terapi

\begin{abstract}
Asthenopia (eye strain) is the group of symptoms comprising the problem of visual, ocular, and musculoskeletal that usually occurs intermittently. This problem occurs due to the long term usage of digital devices especially for the daily usage of more than 6 hours. Asthenopia sufferers is more than 60 millions people in the world that is dominated by the young age. The main symptoms of asthenopia include dry eye, difficulty of focusing object, eyestrain, and headache. The diagnosis of asthenopia can be done subjectively by using standardised questionnaire or objectively by doing further examination. The examination that is usually done to give more detailed description of asthenopia is measuring the Critical Flicker-fusion Frequency (CFF), blinking frequency, accommodative facility, and light reflexes and pupillary diameter size. The management and therapy of asthenopia is given to relieve the symptoms and treat the causes like the treatment to relieve dry eyes, correction of refractive errors, treatment of accommodative and vergence anomalies, and the use of blue-filter spectacles. Although asthenopia occurs intermittently, this disease could develop persistent symptoms and progresses to permanent problems. This article is written based on the literature review of research publications about asthenopia diagnosis, management, therapy. This article is expected to be used as the reference in managing asthenopia cases, so that the prevalence and incidence can be suppressed.
\end{abstract}

Keywords: asthenopia, diagnosis, management, therapy 


\section{PENDAHULUAN}

Asthenopia atau kelalahan mata (eye strain) merupakan kumpulan gejala terkait dengan masalah penglihatan (visual), mata (okular), dan muskuloskeletal. Istilah ini sering digantikan dengan Computer Vision Syndrome (CVS) atau Digital Eye Strain (DES) yang berarti keluhan dicetuskan oleh penggunaan perangkat digital dalam waktu lama (1-4). Gejala yang dirasakan dapat berupa keluhan mata kering, kesulitan dalam memfokuskan objek, mata tegang, mata lelah, dan sakit kepala $(1,3,5)$. Jika tidak ditangani gejala dapat berkembang menjadi gangguan refraksi dan sindrom mata kering yang persistent (6).

Penderita asthenopia di dunia mencapai 60 juta orang $(3,7)$. Prevalensi asthenopia tertinggi berada di usia muda $(8,9)$. Prevalensi yang tinggi ini diakibatkan penggunaan teknologi digital yang semakin banyak (1). Data menunjukkan penggunaan perangkat lebih dari 6 jam memicu kemunculan keluhan ini (10). Berdasarkan angka prevalensi yang tinggi tersebut, asthenopia merupakan permasalahan yang tidak dapat diremehkan dan harus segera mendapatkan perhatian khusus.

Seseorang secara subjektif dapat dikatakan mengalami asthenopia setelah merasakan keluhan-keluhan khas yang dapat ditanyakan menggunakan beberapa kuesioner standar yang sesuai. Untuk mengonfirmasikan diagnosis asthenopia, sejumlah pemeriksaan lanjutan dapat dilakukan. Pemeriksaan tersebut mencakup pemeriksaan Critical Flickerfusion Frequency (CFF), pengukuran frekuensi berkedip, kemampuan akomodasi, dan refleks cahaya dan ukuran pupil (1).

Fokus utama dalam penanganan asthenopia mencakup tatalaksana dan terapi untuk meredakan gejala dan mengatasi penyebab yang mendasari. Asthenopia dipengaruhi beragam faktor risiko yang harus dihindari untuk dapat mencegah kemunculan penyakit ini kembali, karena penyakit ini umumnya terjadi secara intermittent. Tatalaksana dan terapi yang umumnya dilakukan berupa terapi untuk mengatasi mata kering, koreksi gangguan refraksi, terapi gangguan akomodasi dan vergensi, dan penggunaan kacamata filter cahaya biru (1).

Penulisan artikel ini bertujuan untuk membahas mengenai diagnosis, tatalaksana, dan terapi asthenopia sebagai penyakit dengan prevalensi cukup tinggi di dunia dengan dampak yang serius apabila dibiarkan tanpa diberikan tatalaksana yang jelas. Artikel ini diharapkan dapat dijadikan acuan bagi para tenaga kesehatan dalam menindaklanjuti pasien dengan keluhan asthenopia sehingga prevalensi dan insidensinya dapat ditekan.

\section{METODE}

Penulisan artikel ini berdasarkan metode literature review dari artikel penelitian terkait dengan diagnosis, tatalaksana, dan terapi asthenopia yang sudah terpublikasi. Artikel penelitian didapatkan berdasarkan hasil penelusuran pada platform PubMed, Science Direct, dan Google Scholar dengan memasukkan kata kunci yang telah ditentukan sesuai dengan judul artikel. Artikel yang digunakan merupakan artikel yang dipublikasikan pada 10 tahun terakhir yaitu mulai dari tahun 2011 hingga tahun 2021.

\section{HASIL DAN PEMBAHASAN}

Asthenopia dalam bahasa indonesia sederhana sering disebut sebagai kelalahan mata (eye strain) merupakan suatu istilah yang menunjukkan kumpulan gejala yang dirasakan oleh seseorang terkait dengan masalah penglihatan (visual), mata (okular), dan muskuloskeletal. Dalam beberapa artikel istilah ini sering digantikan dengan Computer Vision Syndrome (CVS) atau Digital Eye Strain (DES) yang memiliki arti lebih spesifik yakni gejala yang timbul dicetuskan oleh penggunaan gawai dalam durasi yang lama (1-4). Gejala yang dirasakan umumnya sementara, dapat berupa keluhan mata kering, kesulitan dalam memfokuskan objek, mata tegang, mata lelah, dan sakit kepala $(1,3,5)$. Gejala lain yang dapat menyertai 
asthenopia diantaranya berupa dizziness, mata merah dengan disertai gatal, nyeri pada daerah mata, nyeri leher dan bahu, bahkan dapat menyebabkan hilangnya konsentrasi $(5,10,11)$. Keluhan yang dilaporkan menjadi permasalahan lebih dari 20 tahun ini kendati demikian dapat terjadi berulang kali dan persistent $(1,3)$. Penderita umumnya mengeluhkan adanya gangguang refraksi dan sindrom mata kering yang terjadi setelah dirasakan asthenopia yang persistent (6).

Kejadian asthenopia di dunia tergolong cukup tinggi yakni sebanyak 60 juta orang dilaporkan mengalami asthenopia $(3,7)$. Usia muda merupakan usia dengan prevalensi asthenopia tertinggi $(8,9)$. Prevalensi yang tinggi ini timbul akibat penggunaan teknologi digital yang kian terus bertambah (1). Data menunjukkan penggunaan perangkat lebih dari 6 jam memicu kemunculan keluhan ini (10). Suatu penelitian mengungkapkan bahwa dari seluruh pengguna perangkat digital dilaporkan sekitar 90\%-nya mengalami asthenopia (10).

Hingga saat ini mekanisme fisiologis yang mendasari timbulnya asthenopia masih belum diketahui secara pasti. Hal ini membuat penegakan diagnosis hingga saat ini umumnya menggunakan penegakan diagnosis secara subjektif. Dalam menentukan seseorang mengalami asthenopia secara objektif, saat ini dapat menggunakan beberapa modalitas yang dapat mengukur parameter terkait dengan tanda dan bukti objektif pada asthenopia tersebut $(1,10)$.

Seseorang dapat diketahui mengalami asthenopia secara subjektif adalah berdasarkan tanda dan gejala yang dialami. Untuk menentukannya dapat ditanyakan menggunakan kuesioner standar asthenopia. Kuesioner standar ini merupakan kuesioner yang mencakup seluruh gejala dan tanda seseorang mengalami asthenopia yang dimana validitas dan reabilitasnya telah diuji sehingga dapat menjadi kuesioner standar yang dapat digunakan pada semua orang. Banyak kuesioner standar yang dapat digunakan, salah satunya adalah Computer Vision Syndrome
Questionnaires (CVS-Q) hasil rancangan Segui et al. yang dipublikasikan pada tahun 2015 (1,9,12). Kuesioner standar asthenopia pertama yang menggunakan bahasa inggris ini berisi mengenai 16 gejala umum yang dirasakan penderita asthenopia. Gejala umum tersebut diukur berdasarkan skor frekuensi dan intensitasnya dengan interpretasi hasil dibagi menjadi 4 kategori diantaranya, tidak mengalami asthenopia (0-5), asthenopia derajat ringan (6-12), asthenopia derajat sedang (13-18), dan asthenopia derajat berat (19-32). Pengukuran secara subjektif tersebut dinilai cukup efisien dan diharapkan dapat dijadikan parameter acuan standar dalam screening asthenopia serta dapat dijadikan pertimbangan lebih lanjut untuk dilakukan pengukuran secara objektif $(1,12)$.

Pengukuran secara objektif dapat dilakukan untuk membantu mengonfirmasi seseorang mengalami asthenopia setelah dilakukan pengukuran secara subjektif. Beberapa pemeriksaan yang dapat dipertimbangkan untuk mengetahui apakah seseorang mengalami asthenopia diantaranya berupa pengukuran Critical Flicker-fusion Frequency (CFF), pengukuran frekuensi berkedip, kemampuan akomodasi, dan refleks cahaya dan ukuran pupil $(1,7,13)$.

Pemeriksaan Critical Flicker-Fusion Frequency (CFF) merupakan pengukuran standar dalam menentukan keadaan kelelahan dan beban kerja mental pada seseorang. Pemeriksaan ini dapat mengamati penurunan aktivitas pada retina atau saraf optik apabila hasilnya menunjukan penurunan dari nilai acuan. Hasil serupa menunjukkan adanya keterkaitan dengan keluhan asthenopia yang dimana penurunan nilai dari pemeriksaan tersebut juga berhubungan dengan meningkatnya durasi pekerjaan yang dilakukan seseorang $(1,13)$.

Pengukuran objektif lainnya dapat berupa pengukuran frekuensi berkedip dan penyipitan pada mata (squinting) yang cenderung terjadi ketika menatap layar perangkat digital. Dalam menjaga lapisan permukaan mata tetap normal, berkedip merupakan hal yang efektif 
dilakukan sehingga permukaan mata tidak kering. Pada kondisi asthenopia umumnya berkaitan dengan keluhan mata kering $(1,7)$. Hal ini menandakan bahwasanya terjadi penurunan frekuensi berkedip pada penderita asthenopia. Penggunaan perangkat digital dalam waktu lama cenderung membuat seseorang menyipitkan matanya untuk memeperoleh fokus yang baik akibat tuntutan kognitif yang tinggi atau tingkat keterbacaan rendah yang memerlukan waktu yang lebih lama dalam memperoleh informasi visual sehingga membuat penurunan frekuensi berkedip. Maka dari itu, pengukuran terkait dengan seberapa banyak seseorang berkedip dapat dijadikan acuan untuk mengetahui seseorang mengalami asthenopia. Selain itu, pengukuran terkait dengan keadaan penyipitan mata saat melakukan pekerjaan menggunakan perangkat digital dalam waktu lama tersebut dapat diamati dengan pengukuran electromyography (EMG). Hasil berupa respon yang meningkat menunjukan adanya kecenderungan mata mengalami penurunan frekuensi berkedip. Kendati demikian, hal tersebut masih belum dapat dijadikan pertimbangan pasti akibat adanya perbedaan hasil pada penelitian lain (1).

Keadaan menatap perangkat dalam waktu yang cukup lama mempengaruhi kondisi yang disebut Lag of Accomodation yang menandakan adanya perubahan kemampuan akomodasi pada mata (1). Kondisi tersebut dapat diukur dengan menggunakan dinamic retinoscopy. Ketika melihat objek yang dekat, mata akan berusaha melakukan akomodasi untuk mendapatkan fokus yang baik $(1,3,10)$, hal ini mempengaruhi kemunculan Accomodative Microfluctuations (AMF) yang berarti keadaan tremor atau instabilitas okular di sisi temporal akibat spasme dari otot siliaris. Asthenopia sering terjadi pada keadaan amplitudo akomodasi mata yang rendah, hal ini terjadi saat melihat benda dekat dalam waktu yang lama. AMF dapat dibedakan menjadi 2 tipe, diantaranya adalah low frequency component $(<0,6 \mathrm{~Hz})$ dan high frequency component $(1,0-2,3 \mathrm{~Hz})$.
Pengukuran $A M F$ ini dapat dilakukan dengan mengamati perubahan yang terjadi pada kekuatan refraksi mata dari waktu ke waktu dengan alat optometer atau auto-refraktor. Keadaan asthenopia ditunjukkan oleh peningkatan respon $A M F$ $(1,14)$.

Adanya perubahan karakteristik dan respon pupil dapat menandakan adanya potensi menderita asthenopia. Pada pengukuran diameter pupil ketika bekerja apabila menunjukkan hasil yang meningkat menandakan adanya asthenopia akibat keadaan mata yang terus-menerus mempertahankan fokusnya terutama ketika melihat benda yang dekat. Efek lanjutan yang dapat terjadi adalah penurunan diameter pupil dan peningkatan amplitudo dari refleks pupil akibat adanya spasme sfingter pupillae dan otot siliaris. Pengamatan ukuran pupil dapat dilakukan dengan menggunakan alat open-view autorefractor (1).

Keluhan mata kering merupakan gejala yang cukup sering dirasakan oleh penderita asthenopia. Kondisi lingkungan dapat memicu atau memperparah kemunculan keluhan tersebut $(1,3,7,10)$. Beberapa kondisi seperti kelembaban ruangan atau lingkungan yang rendah, penggunaan air conditioner ataupun kipas angin, serta kondisi lingkungan yang banyak debu mempengaruhi hal tersebut. Selain itu, posisi tubuh atau pandangan ketika menatap layar perangkat secara horizontal menyebabkan bukaan palpebra yang cenderung lebih lebar sehingga terjadi evaporasi lapisan air mata lebih banyak dan lebih cepat dibandingkan dengan posisi yang menghadap ke bawah. Untuk mengurangi gejala yang dirasakan, penggunaan tetes mata lubrikan dapat membantu, namun tidak menghilangkan penyebab secara permanen $(1,7,10,11)$. Penelitian membuktikan bahwa makan makanan yang mengandung supplemen asam lemak omega-3 dapat memperbaiki kondisi tersebut. Disamping itu, latihan berkedip (blinking training) dapat membantu mengurangi kebiasaan berkedip yang tidak sempurna, sehingga lapisan air mata dapat lebih terjaga 
dengan baik dan keluhan mata kering menjadi berkurang (1).

$\begin{array}{ccc}\text { Gangguan refraksi } & \text { seringkali } \\ \text { menjadi dasar munculnya } & \text { keluhan } \\ \text { asthenopia pada } & \text { seseorang terutama }\end{array}$ pada astigmatisma dan/atau presbiopia. Koreksi gangguan refraksi pada individu tersebut akan membantu memperbaiki keluhan yang dialami $(1,7,10,13)$. Sebuah penelitian menunjukkan orang dengan gangguan refraksi bahkan yang rendah sekalipun (0,5 - 1,0 D) dapat memberikan pengaruh negatif terhadap kenyamanan visual seseorang (1,13). Kebiasaan menggunakan perangkat dengan layar kecil akan mempengaruhi huruf-huruf atau objek yang ditampilkan cenderung lebih kecil, sehingga hal ini sebisa mungkin dihindari pada kondisi orang dengan gangguan refraksi tersebut. Selain itu, hal yang perlu dihindari adalah jarak pandang dengan layar perangkat digital yang kurang dari $50 \mathrm{~cm}$. Koreksi gangguan refraksi ini harus dilakukan oleh dokter dengan tepat dan dapat menangani permasalahan yang mendasari dengan melakukan anamnesis lengkap terakit dengan kondisi lingkungan tempat tinggal dan bekerja pasien. Dokter juga harus dapat memberikan edukasi berupa saransaran yang lengkap terkait dengan posisi saat bekerja tersebut sehingga keluhan yang dirasakan oleh pasien dapat diperbaiki, setidaknya diminimalisir atau tidak bertambah parah (1).

American Optometric Association mengeluarkan aturan (rules) 20-20-20 yang dapat dilakukan untuk mengurangi ataupun mencegah kemunculan gejala asthenopia. Adapun aturan tersebut menyarankan pengguna perangkat digital untuk melakukan istirahat selama 20 detik setiap 20 menit dengan melihat objek sejauh 20 feet $(1,5)$. Prosedur tersebut memberikan mata kesempatan untuk merelaksasi respon akomodasi dan vergensi, sehingga keluhan asthenopia akan berkurang $(1,13)$.

Paparan sinar biru dengan panjang gelombang 400-500 nm dapat membahayakan retina sehingga rentan terhadap kemunculan keluhan asthenopia. Paparan yang tidak sering namun dengan durasi yang panjang juga dapat menyebabkan kerusakan retina $(1,15)$. Teknologi layar terbaru (LEDs) memancarkan radiasi inframerah yang lebih rendah namun dengan radiasi sinar biru yang lebih tinggi, sehingga sangat disarankan bagi penggunanya menggunakan kacamata filter cahaya biru. Penggunaan kacamata filter cahaya biru ini dapat mengurangi radiasi sinar biru sebesar 10,6\%-23,6\% (1). Penelitian mengungkapkan bahwa penggunaan kacamata tersebut membantu menurunkan gejala asthenopia yang dialami seseorang terutama untuk keluhan mata kering $(1,15)$.

\section{KESIMPULAN}

Asthenopia merupakan keluhan yang umum dirasakan oleh sebagian orang terutama bagi pengguna perangkat digital dalam durasi yang lama. Keluhan ini pada dasarnya bersifat hilang timbul (intermittent). Meskipun demikian, kemunculan keluhan ini tidak dapat diabaikan karena apabila dibiarkan keluhan dapat menjadi menetap (persistent) yang dapat berkembang menjadi kerusakan permanen seperti gangguan refraksi dan sindrom mata kering sehingga lebih sulit untuk disembuhkan. Penggunaan kuesioner standar asthenopia dinilai efektif dalam melakukan screening penderita asthenopia. Para pengguna perangkat digital dalam durasi yang cukup lama sebaiknya dilakukan screening ini. Apabila diagnosis asthenopia sudah ditegakkan, pemilihan tatalaksana atau terapi harus disesuaikan sesuai dengan keluhan yang dirasakan setiap orang sehingga terapi yang diberikan menjadi lebih efektif dan efisien.

\section{DAFTAR PUSTAKA}

Sheppard AL, Wolffsohn JS. Digital eye strain: Prevalence, measurement and amelioration. BMJ Open Ophthalmol. 2018;3(1).

Kim DJ, Lim C-Y, Gu N, Park CY. Visual Fatigue Induced by Viewing a Tablet Computer with a Highresolution Display. Korean J Ophthalmol. 2017;31(5):388.

Sari FTA, Himayani R. Faktor Risiko 
Terjadinya Computer Vision Syndrome Risk Factors Occurrence of Computer Vision Syndrome. Majority. 2018;Vol.7 No.2(Maret):278-82.

Dessie A, Adane F, Nega A, Wami SD, Chercos DH. Computer vision syndrome and associated factors among computer users in Debre Tabor town, Northwest Ethiopia. J Environ Public Health. 2018;2018.

Akinbinu TR, Mashalla YJ. Medical Practice and Review Impact of computer technology on health: Computer Vision Syndrome ( CVS ). Acad Journals. 2014;5(November):20-30.

Bogdănici CM, Săndulache DE, Nechita CA. Eyesight quality and Computer Vision Syndrome. Rom J Ophthalmol. 2017;61(2):112-6.

Alemayehu AM. Pathophysiologic Mechanisms of Computer Vision Syndrome and its Prevention: Review. World J Ophthalmol Vis Res. 2019;2(5):1-7.

Ranganatha, Jailkhani S. Prevalence and Associated Risk Factors of Computer Vision Syndrome among the Computer Science Students of an Engineering College of Bengaluru-A Cross-Sectional Study. Galore Int J Heal Sci Res. 2019;4(July):10.

Mohan A, Sen P, Shah C, Jain E, Jain S. Prevalence and risk factor assessment of digital eye strain among children using online elearning during the COVID-19 pandemic: Digital eye strain among kids (DESK study-1). Indian J Ophthalmol. 2021;69(1):140.

Gowrisankaran S, Sheedy JE. Computer vision syndrome: A review. Work. 2015;52(2):303-14.

Sawaya RT, El Meski N, Saba J, Lahoud C, Saab L, Haouili M, et al. Asthenopia among university students: The eye of the digital generation. J Fam Med Prim Care. 2020;9(8):3921.

Seguí MDM, Cabrero-García J, Crespo A, Verdú J, Ronda E. A reliable and valid questionnaire was developed to measure computer vision syndrome at the workplace. J Clin Epidemiol [Internet]. 2015;68(6):662-73. Available from: http://dx.doi.org/10.1016/j.jclinepi.2 015.01 .015

Bali J, Neeraj N, Bali R. Computer vision syndrome: A review. J Clin Ophthalmol Res. 2014;2(1):61.

Kajita M, Muraoka T, Orsborn G. Changes in accommodative microfluctuations after wearing contact lenses of different optical designs. Contact Lens Anterior Eye. 2020;43(5):493-6.

Dabrowiecki A, Villalobos A, Krupinski EA. Impact of blue light filtering glasses on computer vision syndrome in radiology residents: a pilot study. $\mathrm{J}$ Med Imaging. 2019;7(02):1. 